\title{
INDOOR AIR QUALITY AND MECHANICAL VENTILATION FOR TECHNOLOGY BUILDINGS
}

\author{
${ }^{1}$ Zuzana STRAKOVA, ${ }^{2}$ Jan TAKACS \\ Slovak University of Technology in Bratislava, Faculty of Civil Engineering \\ Department of Building Services, Radlinskeho 11, 81005 Bratislava, Slovak Republic \\ e-mail: ${ }^{1}$ zuzana.strakova@stuba.sk, ${ }^{2}$ jan.takacs@stuba.sk
}

Received 29 November 2016; accepted 13 March 2017

\begin{abstract}
Creating of indoor environment in the work area in industrial buildings should be based on cooperation between heating and ventilation. However, practice shows that this is not truth in many cases. Both professions are many times designed separately. Result is their noncooperation leading to a mutual obstruction in terms of disposal location or functional operation of the systems. Creating a heating and ventilation system, which would both be designed in accordance with applicable legislation and it would create an optimal indoor environment for people in working area, to find solution in combination of radiant heating with ventilation air recovery unit.
\end{abstract}

Keywords: Indoor air quality, Ventilation, Radiant heating; Heat recovery unit

\section{Introduction}

Every design of Heating, Ventilating and Air Conditioning (HVAC) in project activity is based on a large number of assumptions whose veracity is supported either in theory (literature) or by experience-based knowledge. However, there are cases with a unique input, or with a brand new, yet uncommon HVAC system. Unfortunately, all other modifications and repairs result in increased investment costs compared to the forecasted ones [1], [2].

In other cases, it is not unusual that the expected parameters of the internal environment calculated by the designer are not being reached after implementation.

A computer analysis on a defined model of an industrial building may be very beneficial for solving this issue. It can be verified whether the proposed system will or 
will not bring the expected results in creation of thermal comfort in the work area of a human and whether this creation of the 'comfort for a human' will not be at the expense of too high energy consumption [3], [4].

The aim of this article is to introduce the technical solution that brings the benefits both on the energy savings, as well as in achieving optimal microclimate for the man in his work area.

\section{Principles of cooperation of the two systems}

Radiant heating system is designed to cover the heat loss in winter. Suspended radiant panels provide thermal energy to the heated space mainly by radiation $(70 \%)$. The radiant component heats the building structures constituting the internal space walls and floors, from which, in turn, the internal air inside the work area is heated. The convection component by the performance of radiant panels $(30 \%)$ rises by convection (flow) upwards into the roof space of the hall where it diminishes in form of heat loss by the roof structure. Yet, this lost heat can be used in a heat recovery air unit for heating (or preheating) of fresh, but cool outdoor air, designed for sanitary ventilation of an industrial building. The principles of the vertical airflow through large surface diffusers are suitable for sanitary ventilation. Thanks to their length, they are a suitable distribution element - shown in Fig. 1. The accumulated heat capacity of air from the neutral zone and the energy performance zone of the building is of use to the recovery unit by in-taking of the warm air from the space under the roof through the suction elements (e.g. a single row rectangular diffuser) [5].

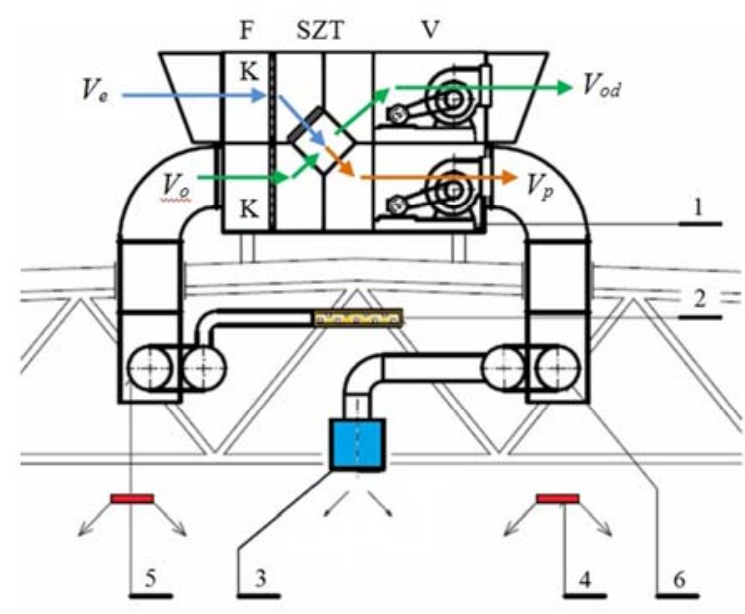

Fig. 1. Ventilation recovery unit with central air distribution via volume diffusers [6] 1 is the recovery unit; 2 is the rectangular single row diffuser (air discharge); 3 is the volume diffuser (air supply); 4 is the suspended radiant panel; 5 is the air channel for exhaust air; 6 is the air channel for supply air; $V_{e}$ is the external air flow; $V_{p}$ is the supply air flow; $V_{o}$ is the discharge air flow; $V_{o d}$ is the waste air flow; $\mathrm{K}$ is the flap; $\mathrm{F}$ is the filter; SZT is the reverse heat gain in heat recovery exchanger; $\mathrm{V}$ is the fan 
Consequently, it is piped by the air channel into the plate heat exchanger in a heat recovery unit where the air transmits its heat energy to the colder outside intake air, which is heated to an acceptable temperature in regard to recovery heat exchanger efficiency. As mentioned above, this air is blown by the large-volume diffusers into the space below the suspended radiant panels. In this area, it is mixed with the warmer internal air inside, and such compressed air slowly descends into the work area where it reaches the desired calculated internal temperature. The thermal energy necessary for additional heating of the external from the air temperature behind recovery heat exchanger to the internal calculated temperature of air has to be delivered to the heated area by increased thermal performance of radiant panels [7], [8].

\section{The model of a hall storage building}

The example of calculation and design of systems in combination of sanitary ventilation with radiant heating is used in the construction of one-floor, single-aisle free-standing hall building with socio-administrative annex situated at the head of the building (Fig. 2).

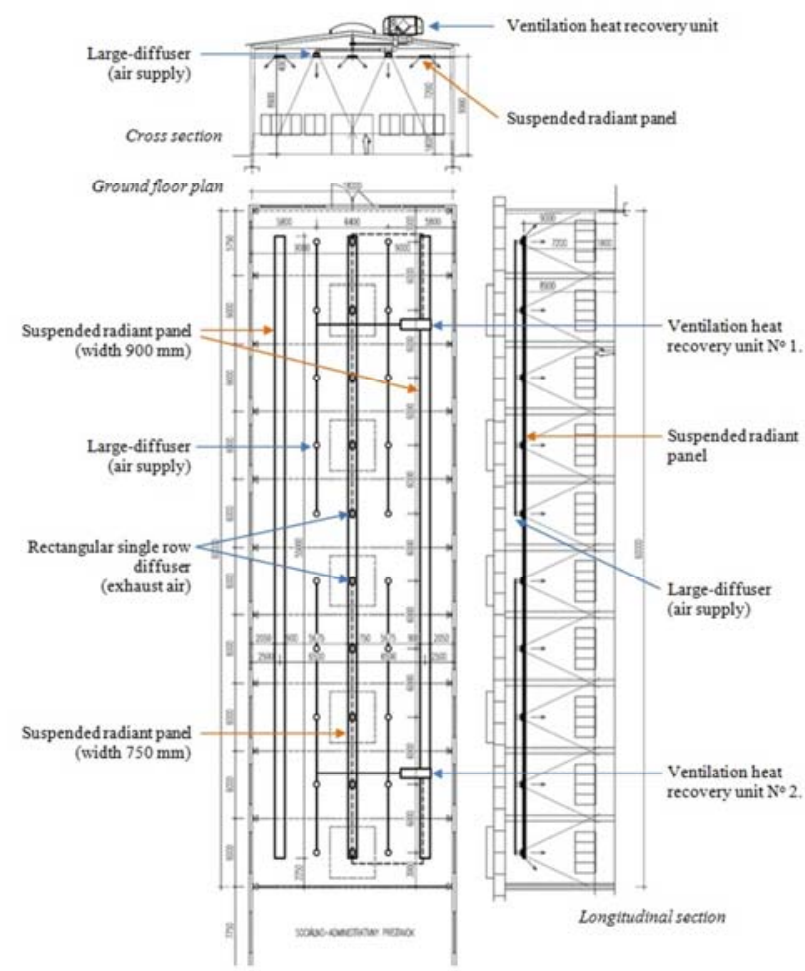

Fig. 2. The ground floor plan, the cross and longitudinal section of an industrial building and a diagram of the combined system [6] 
It is a storage building with a frequent intake and outtake of goods. The building situated in the city of Bratislava (Slovakia) belongs - in terms of the area type - to the first temperature range zone in winter $\left(\theta_{e}=-11^{\circ} \mathrm{C}\right)$, to the second wind zone with wind speed between $2-5 \mathrm{~m} / \mathrm{s}$ and to A-temperature zone in the summer $\left(\theta_{e, m}=20.5^{\circ} \mathrm{C}\right)$ [9], [10].

\subsection{Defining the external environment parameters}

When calculating the heat gain within the meaning of STN 73 0548:1985, the ambient temperature $\theta_{e}=30{ }^{\circ} \mathrm{C}$ is considered (Fig. 3). However, in the calculation of the heat gain from the outside air intake, it is preferable to consider a higher temperature of $\theta_{e}=35^{\circ} \mathrm{C}$, so that the HVAC unit regulation could guarantee the required indoor air temperature of $\theta_{i}=26{ }^{\circ} \mathrm{C}$ during extremely warm summer days, although the legislation allows to reduce the intake of outside air to its half value for a short period in case of maximum outside air temperatures [11], [12], [13].

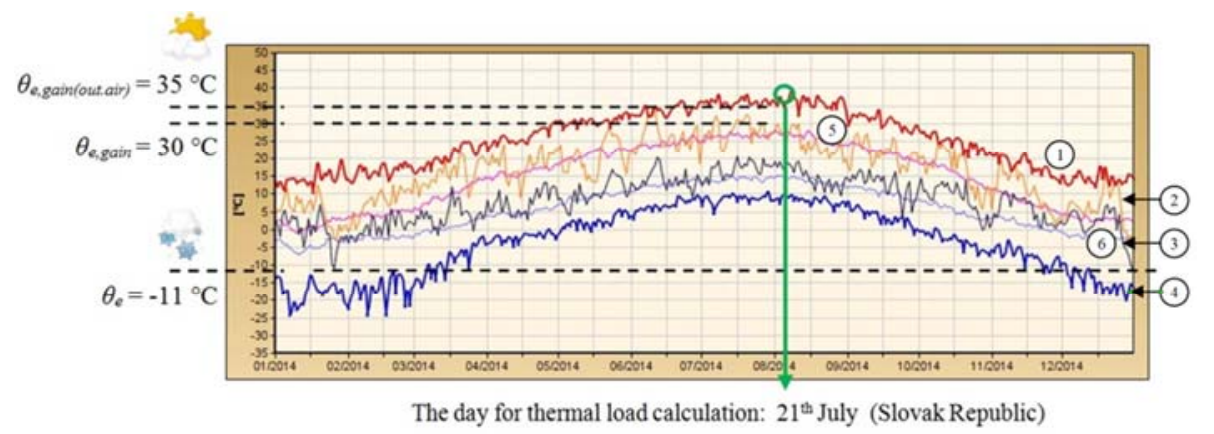

Fig. 3. The maximum and minimum outdoor air temperature - Bratislava - airport 2014

1 is the absolute maximum daily air temperature for the period 1951-2013; 2 is the daily maximum air temperature for the year $2014 ; 3$ is the daily minimum air temperature for the year 2014 ; 4 is the absolute minimum daily air temperature for the period $1951-2013 ; 5$ is the longterm average daily maximum air temperature for the period 1961-1990; 6 is the long-term average daily minimum air temperature for the period 1961-1990 [11]

When the intensity of solar radiation changes so does the intensity of diffuse solar radiation as well as the outside air temperature $\theta_{e}$ (Table I).

\section{Table I}

The average outdoor temperature $\theta_{e}\left({ }^{\circ} \mathrm{C}\right)$ per month

\begin{tabular}{|l|c|c|c|c|c|c|c|c|c|c|c|c|}
\hline Month & I. & II. & III. & IV. & V. & VI. & VII. & VIII. & IX. & X. & XI. & XII. \\
\hline Temperature $\theta_{e}$ & -11 & -5 & +10 & +15 & +20 & +25 & +30 & +27 & +20 & +10 & 0 & -8 \\
\hline
\end{tabular}




\subsection{Defining the parameters of the internal environment}

Indoor air temperature $\theta_{i}$ and the relative humidity of indoor air $\varphi_{i}$ are important in terms of analysis of the combined system (Table II). The binding regulation refers to the maximum value for the summer season $\left(\theta_{i}=26^{\circ} \mathrm{C}\right)$ and minimum values for the winter season $\left(\theta_{i}=18^{\circ} \mathrm{C}\right)$.

\section{Table II}

Indoor air temperature $\theta_{i}\left[{ }^{\circ} \mathrm{C}\right]$ and relative humidity of indoor air $\varphi_{i}(\%)$

\begin{tabular}{|l|c|c|c|c|c|c|c|c|c|c|c|c|}
\hline Month & I. & II. & III. & IV. & V. & VI. & VII. & VIII. & IX. & X. & XI. & XII. \\
Temperature $\theta_{i}$ & 18 & 18 & $18 \rightarrow 26$ & 26 & 26 & 26 & $26 \rightarrow 18$ & 18 \\
\hline RH $\varphi_{i}$ & \multicolumn{10}{|c|}{$30-70$} \\
\hline
\end{tabular}

\section{Overview of energy balance in each month}

Energy balance in general is the ratio between energy intake and expenditure. In terms of the operation of a building, the balance between the heat load $\Phi_{\text {load }}$ and heat loss $\Phi_{\text {loss }}$ is monitored. It reaches its maximum during the summer and winter, but in inverse proportion - in summer the maximum load and loss is minimal or zero; and vice versa during winter [14], [15]. In the transitional seasons (spring, autumn), these two values converge. When the outside air temperature changes, the required indoor air temperature can be achieved only by the delivery of energy, produced in the form of heat and cold. If the amount of energy consumed equals the amount of energy delivered, then the energy balance is just right. Gradually, the input values for the total energy balance calculation were calculated by using the defined parameters of external and internal environment [16], [17], [18]. The results are shown in the Table III.

The table shows the impact of changing climate of the outside environment on the heat loss and heat loads values inside the industrial building. They are quite different during the year.

For better orientation in these issues the results are shown in Fig. 4 - Fig. 9.

\section{The analysis of combined system operation}

The aim is to find out how their mutual cooperation reflects the need for heat and cooling energy in comparison to a situation where there would be two separate operating systems (ventilation by direct-hot air heating units + heating by radiant panels) [19], [20]. 
Table III

The summary of the energy balance results

\begin{tabular}{|c|c|c|c|c|c|c|c|c|c|c|c|c|}
\hline Month & I. & II. & III. & IV. & $\mathrm{V}$. & VI. & VII. & VIII. & IX. & $\mathrm{X}$. & XI. & XII. \\
\hline \multicolumn{13}{|c|}{ External Environment Parameters } \\
\hline \begin{tabular}{l|} 
Temperature \\
$\theta_{e}\left[{ }^{\circ} \mathrm{C}\right]$
\end{tabular} & -11 & -5 & +10 & +15 & +20 & +25 & +30 & +27 & +20 & +10 & 0 & -8 \\
\hline $\begin{array}{l}\text { Intensity of solar } \\
\text { radiation } \\
I_{o}\left[\mathrm{~W} / \mathrm{m}^{2}\right]\end{array}$ & 710 & 700 & 674 & 596 & 558 & 492 & 511 & 598 & 575 & 558 & 550 & 540 \\
\hline $\begin{array}{l}\text { Intensity of diffuse } \\
\text { solar radiation } \\
I_{o, d i f}\left[\mathrm{~W} / \mathrm{m}^{2}\right]\end{array}$ & 10 & 45 & 75 & 100 & 112 & 122 & 117 & 99 & 78 & 50 & 25 & 7 \\
\hline \multicolumn{13}{|c|}{ Internal Environment Parameters } \\
\hline \begin{tabular}{l|} 
Temperature \\
$\theta_{i}\left[{ }^{\circ} \mathrm{C}\right]$
\end{tabular} & 18 & 18 & 18 & 18 & 20 & 25 & 26 & 26 & 20 & 18 & 18 & 18 \\
\hline $\mathrm{RH} \varphi_{i}[\%]$ & \multicolumn{12}{|c|}{$30-70$} \\
\hline \multicolumn{13}{|c|}{ Calculated values of energy balance } \\
\hline $\begin{array}{l}\text { Thermal gains } \\
\Phi_{\text {gains }}[\mathrm{W}]\end{array}$ & 0 & 0 & 34050 & 38417 & 40842 & 38460 & 38630 & 36403 & 34467 & 29336 & 0 & 0 \\
\hline $\begin{array}{l}\text { Thermal gain } \\
\text { (outdoor air) }\end{array}$ & 0 & 0 & 0 & 0 & 0 & 0 & 43414 & 40953 & 0 & 0 & 0 & 0 \\
\hline$\Phi_{e, \text { gain }}[\mathrm{W}]$ & & & & & & & & & & & & \\
\hline $\begin{array}{l}\text { Thermal load } \\
\Phi_{\text {load }}[\mathrm{W}]\end{array}$ & 0 & 0 & 34050 & 38417 & 40842 & 38460 & 82044 & 77356 & 34467 & 29336 & 0 & 0 \\
\hline \multicolumn{13}{|c|}{ Supply of heat energy _ Heating system (Radiant ceiling panels) } \\
\hline \begin{tabular}{l|} 
Heat output \\
$\Phi_{\text {panels }}[\mathrm{W}]$ \\
\end{tabular} & 86326 & 62404 & 28321 & 14424 & 0 & 0 & 0 & 0 & 0 & 28321 & 51043 & 73523 \\
\hline \multicolumn{13}{|c|}{ Supply of heat and cooling energy _ HVAC system (Ventilation recuperative unit) } \\
\hline $\begin{array}{l}\text { Air temperature } \\
\text { (under the roof) } \\
\theta_{i, t v}\left[{ }^{\circ} \mathrm{C}\right] \\
\text { Air temperature }\end{array}$ & 19.50 & 20.24 & 21.16 & 21.53 & 20 & 25 & 26 & 26 & 20 & 21.16 & 21.92 & 19.45 \\
\hline $\begin{array}{l}\text { Air temperature } \\
\text { (behind heat exch.) }\end{array}$ & 17 & 18 & 19 & 20 & 20 & 28 & 28 & 28 & 20 & 19 & 19 & 18 \\
\hline $\begin{array}{l}\theta_{i, \text { rec }}\left[{ }^{\circ} \mathrm{C}\right] \\
\text { Efficiency of heat }\end{array}$ & & & & & & & & & & & & \\
\hline $\begin{array}{l}\text { Efficiency of heat } \\
\text { exchanger } \\
\eta_{h e}[\%]\end{array}$ & 93 & 90 & 76 & 75 & 75 & 75 & 75 & 76 & 76 & 78 & 88 & 91 \\
\hline $\begin{array}{l}\text { Heat output heater } \\
\Phi_{h}[\mathrm{~W}]\end{array}$ & 600 & 200 & - & - & - & - & - & - & - & - & - & 600 \\
\hline $\begin{array}{l}\text { Cooling output } \\
\text { cooler } \Phi_{c}[\mathrm{~W}]\end{array}$ & - & - & - & - & 41012 & 42760 & 83580 & 78360 & 35704 & - & - & - \\
\hline
\end{tabular}




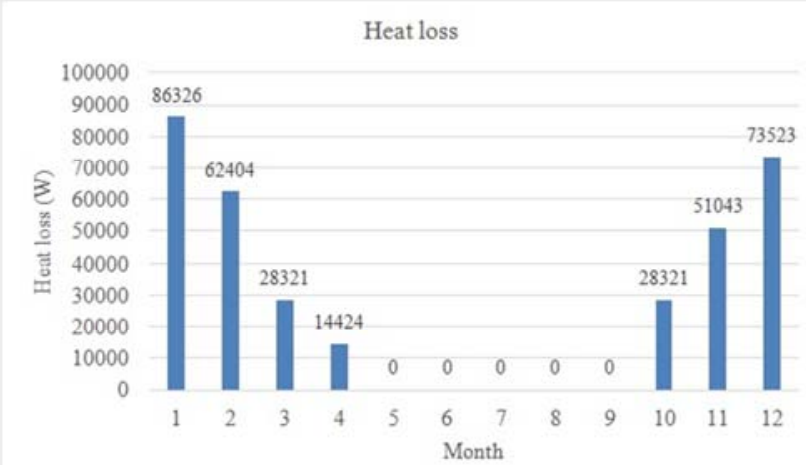

Fig. 4. Heat loss of large area storage building

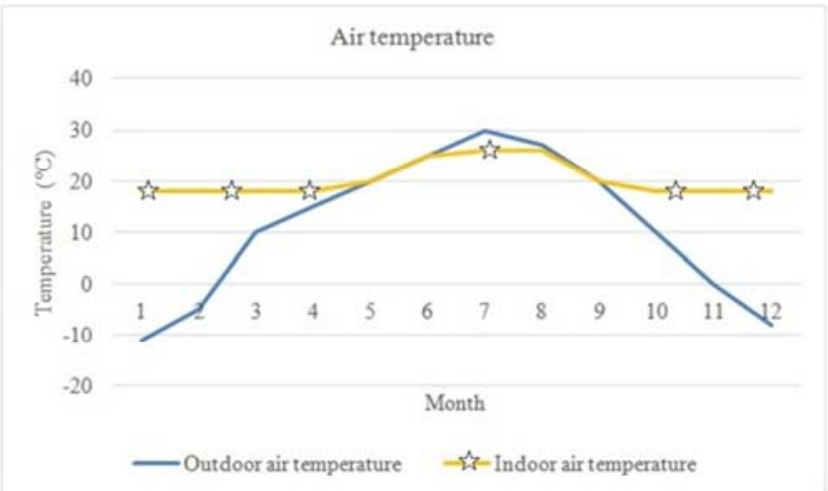

Fig. 5. Progress of outdoor and indoor temperature during whole year

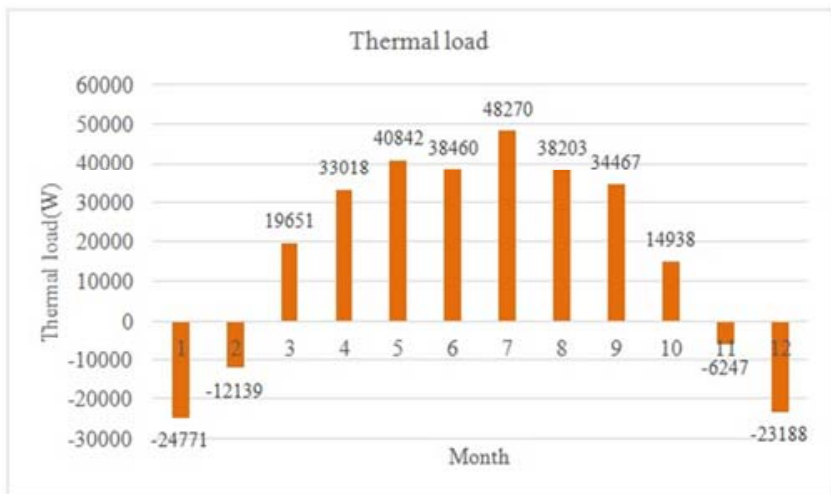

Fig. 6. Thermal load of large area storage building 


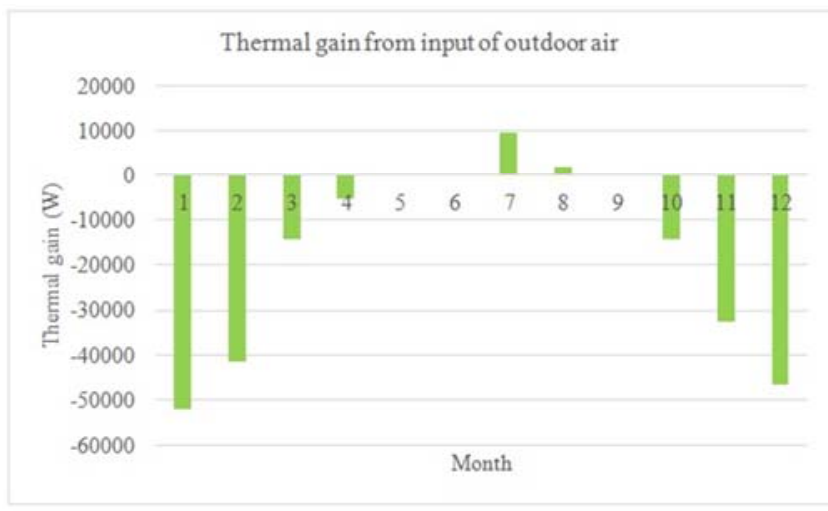

Fig. 7. Thermal gain from outdoor air

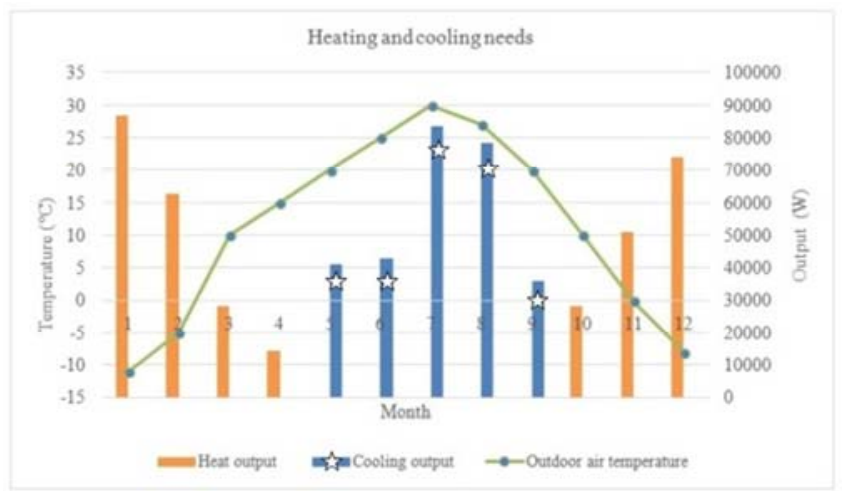

Fig. 8. Heating and cooling needs in relation to outside air temperature (the combined system)

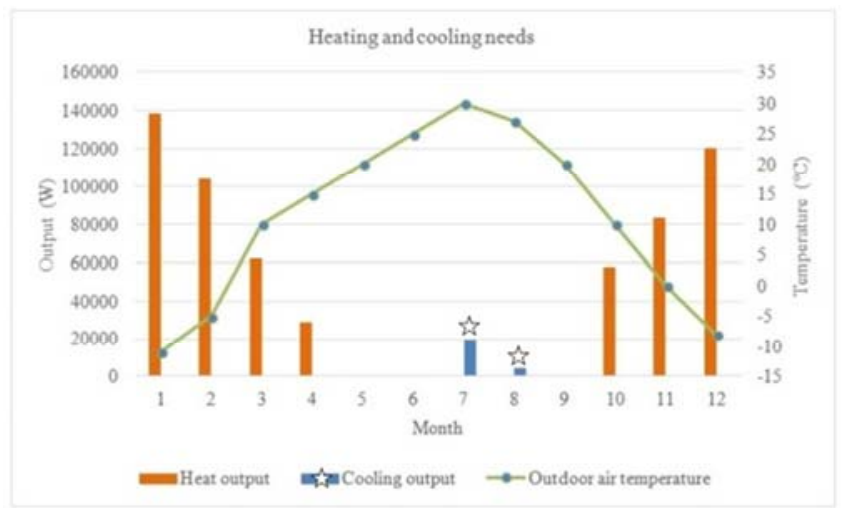

Fig. 9. Heating and cooling needs in relation to outside air temperature (two separate systems)

Pollack Periodica 12, 2017, 2 


\section{Conclusion}

Based on the analysis of the graphical outputs, it can be stated that the numbers speak clearly in favor of the combined system.

As it can be seen from the results, the combined system partly needs a heat and cooling energy during whole year in relation to outside air temperature. But compared to separate systems maximum heating needs is higher by $37 \%$ against the separate systems (combined system approximately $87 \mathrm{~kW}$, separate system approximately 139 $\mathrm{kW}$ ) in winter period.

As for the summer period, a separate system does not solve inside microclimate in no way. Inside air temperature mostly reaches the value $29{ }^{\circ} \mathrm{C}$ or higher, which is unacceptable from a health perspective. Therefore, the cooling needs is necessary.

Thanks to its function and mutual cooperation we can achieve significant energy savings in comparison to the ventilation system with direct ventilation while meeting the requirements of the internal working environment.

\section{References}

[1] Kotrbatý M., Hojer O., Kovářová Z. Heat management in industry, 'The cheapest is the saved energy' (in Slovak), České Sdružení pro Technická Zařízení, Praha, 2009.

[2] Hojer O. The zone method in the design of heating of large objects, (in Slovak) Procceding on Conference of Vytápění, Třeboň, Czech Republic, 14-16 May 2013, pp. 42-47.

[3] Blasinski P., Frič L., Jelínek O. Evaluation of heat recovery ventilation system during its operation, (in Slovak) Český Instalatér, Vol. 25, No. 2, 2015, pp. 28-31.

[4] Hirš J., Gebauer G. Ventilation examples, No. 1, Brno, Academic Publishing Books, 2006.

[5] Neelakantan P., Reddy A. R. M. Decentralized load balancing in distributed systems, Pollack Periodica, Vol. 9, No. 2, 2014, p. 15-28.

[6] Straková Z. Hygienic ventilation of industry hall buildings with cold type of operation, (in Slovak) Habilitation Thesis, Faculty of Civil Engineering, Slovak University of Technology in Bratislava, 2015.

[7] Kassai M., Kajtar L. Cooling energy saved investigation of air-to-air heat-and energy exchangers, in Nyers J., Stuparic D., Boros D. (Eds.) Proceedings Express 2016, 8th International Symposium on Exploitation of Renewable Energy Sources and Efficiency, Subotica, Serbia, 31 March - 2 April 2016, pp. 6-10.

[8] Kapalo P. Domnita F. Lojkovics J. Methodology for calculating the fresh air ventilation airflow rate based on $\mathrm{CO}_{2}$ concentration, Pollack Periodica, Vol. 9, No. 2, 2014, p. 89-97.

[9] Gaál P., Veres C. Free cooling - The economic and environmental chilling method, (in Hungarian), Energia Gazdálkodás, Vol. 57, No. 1-2, 2016, pp. 12-13.

[10] Nyers J., Kajtar L., Slavica T., Nyers A. Investment-savings method for energy-economic optimalization of external wall thermal insulation thickness, Energy and Buildings, Vol. 86, 2014, pp. 268-274.

[11] http://www.shmu.sk/sk/?page=1\&id=klimat_operativneudaje1 (last visited 25 April 2015).

[12] Krajč́́k M., Simone A., Olesen B. W. Air distribution and ventilation effectiveness in an occupied room heated by warm air, Energy and Buildings, Vol. 55, 2012, pp. 94-101.

[13] Government Ordinance No. 391/2006, Coll. about the minimum safety and health requirements for the workplace, (in Slovak), Bratislava, 2006.

[14] Pérez-Lombard L., Ortiz J., Pout C. Review on buildings energy consumption information, Energy and Buildings, Vol. 40, 2008, pp. 394-398. 
[15] Kovářová Z. The combination of suspendable radiant panels with hygienic ventilation, (in Hungarian) Magyar Épületgépészet, Vol. 63, No. 5, 2014, pp. 13-16.

[16] Krajčík M., Kudiváni L., Mahdavi A. Energy saving potential of personalized ventilation applied in an open space office under winter conditions, Applied Mechanics and Materials, Vol. 861, 2016, p. 417-424.

[17] Straková Z. The creation of indoor climate in industry operation, Modern Environmental Science and Engineering, Nol. 1, No. 2, 2015, pp. 104-110.

[18] Straková Z., Pribyl P. Central ventilation and local exhaust in wood industrial facilities, The REHVA European HVAC Journal, Vol. 52, No. 3, 2015, pp. 48-52.

[19] Füri B., Kurčová M. Thermodynamics, Exercises, (in Slovak) Bratislava, (Publishers of Slovak University of Technology, 2014.

[20] Malinová K. The new heat source in a 12 levels apartment building, (in Slovak), In: Správa budov, Vol. 6, No. 1, 2012, pp.40-42. 